\begin{tabular}{|l|l|l|l|l|l|}
\hline J. Tek. Ling. & Vol. 10 & No. 1 & Hal. 62 - 68 & Jakarta, Januari 2009 & ISSN 1441-318X \\
\hline
\end{tabular}

\title{
PENGHEMATAN ENERGI PADA INDUSTRI SEMEN Studi Kasus : Pemasangan VSD'S pada Fan
}

\author{
Teguh Prayudi \\ Peneliti di Pusat Teknologi Lingkungan \\ Badan Pengkajian dan Penerapan Teknologi
}

\begin{abstract}
Abstrak
Industri semen merupakan salah satu industri yang digolongkan sebagai industri yang boros mengkonsumsi energi, karena dalam proses produksi mengkonsumsi energi cukup besar setara dengan 25 s/d $35 \%$ dari biaya total produksi. Sejalan dengan semakin berkurangnya cadangan bahan bakar fosil yang tidak dapat diperbaharui (non-renewable energy), penghematan energi melalui efisiensi penggunaan energi pada proses produksi menjadi suatu keharusan yang tidak dapat dihindari.

Dalam penelitian sebelumnya ${ }^{[1]}$, Penulis telah melakukan Feasibility Study terhadap pemasangan VSD di Fan, yang menunjukkan kemungkinan penghematan energi yang cukup besar. Dalam penelitian ini, unjuk kerja dilapangan secara nyata telah didapatkan bahwa pemasangan inverter atau VSD'S pada Fan yang digunakan didalam proses produksi Industri Semen, mampu menghemat penggunaan energi sebesar 499,0464 MWH pertahun, dan nilai ini setara dengan penurunan emisi gas CO2 sebesar 361.309,594 Ton CO2/Tahun.
\end{abstract}

Keywords: Industri Semen, Fan, Damper, Variable Speed Drive (VSD), Inverter.

\section{PENDAHULUAN}

\subsection{Latar Belakang}

Industri semen adalah industri yang banyak memerlukan energi untuk proses produksinya, yaitu bervariasi antara $25 \%$ s/d $35 \%$ dari total biaya produksi. Dengan demikian industri semen termasuk sebagai salah satu industri yang boros energi.

Sejalan dengan kondisi krisis energi yang melanda dunia dan terjadinya fenomena pemanasan global (global warming) saat ini, maka upaya penghematan penggunaan energi, terutama energi yang berasal dari pembakaran bahan bakar fosil perlu menjadi perhatian semuanya.

Timbulnya dampak lingkungan dari penggunaan bahan bakar fosil harus disikapi secara bijaksana dengan melakukan upaya-

upaya pencegahan atau pengurangan dampak tanpa harus mengurangi kinerja maupun produksi suatu kegiatan (industri), seperti optimalisasi proses, peningkatan effisiensi, pemanfaat bahan baku yang ramah lingkungan dan sebagainya. Upaya ini dikenal sebagai prinsip-prinsip metoda produksi bersih.

Dalam industri semen, beberapa proses produksi masih memungkinkan dikaji lebih dalam melalui penerapan prinsip-prinsip produksi bersih tersebut untuk memperoleh efisiensi penggunaan energinya secara langsung akan berdampak pada penekanan biaya produsi dan meningkatkan keuntungan perusahaan. 


\subsection{Tinjauan Pustaka}

Hampir kebanyakan pabrik menggunakan fan untuk ventilasi dan proses industri yang memerlukan aliran udara. Sistim fan penting untuk menjaga pekerjaan proses industri, dan terdiri dari sebuah fan, motor listrik, sistim penggerak, saluran atau pemipaan, peralatan pengendali aliran, dan peralatan penyejuk udara (filter, kumparan pendingin, penukar panas, dan lain lain.). Departemen Energi Amerika Serikat memperkirakan bahwa 15 persen listrik di industri manufakturing Amerika dipakai untuk keperluan motor. Hal yang sama di sektor komersial, listrik yang dibutuhkan untuk mengoperasikan motor fan yang merupakan bagian dari biaya energi terbesar untuk penyejukan ruangan ${ }^{[2]}$ (US DOE, 1989).

Salah satu cara untuk mengurangi beban konsumsi energi fan agar lebih effisien adalah dengan cara pengaturan kecepatan fan untuk mengontrol aliran udara sesuai dengan kebutuhan.

Fan terpasang beroperasi pada kecepatan konstan. Namun beberapa situasi mungkin menghendaki perubahan kecepatan, sebagai contoh lebih banyak aliran udara mungkin diperlukan dari fan ketika ada tambahan sebuah saluran baru, atau mungkin diperlukan aliran udara yang sedikit jika fannya kebesaran.

Beberapa cara menurunkan atau mengendalikan aliran udara fan dapat dilakukan antara lain melalui cara/ metoda pengendali antara lain ${ }^{[2,3]}$ : perubahan pully, penggunaan dampers, Variable Speed Drive (VSD), Inlet Guide vanes, Variable pitch fans,

Perubahan polly dilakukan dengan mengurangi ukuran pully motor atau penggerak yang dimaksudkan untuk menurunkan kecepatan secara permanen dan menurunkan energi secara nyata, sebagaimana terlihat ada gambar dibawah ini dimana dengan penurunan 2 inchi pully menghemat $12 \mathrm{~kW}$.

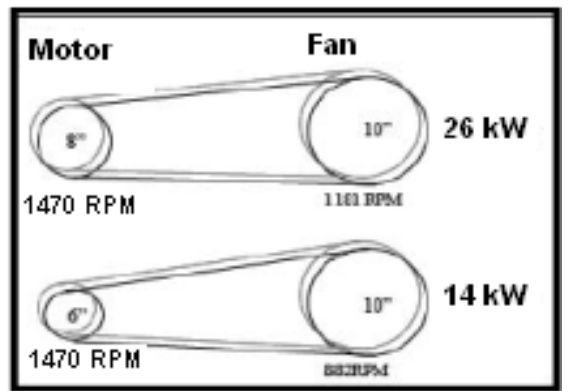

Gambar 1 skema perubahan polly

Penggunaan damper dilakukan untuk mengurangi jumlah aliran dan juga meningkatkan tekanan hulu, yang akan mengurangi keluaran fan. Keuntungan dari penggunaan damper selain murah juga mudah pemasangannya tetapi ada juga kerugiannya yaitu memberikan jumlah pengaturan yang terbatas. Serta walaupun dapat mengurangi aliran tapi tidak dapat mengurangi pemakaian energi. Selain itu biaya operasi dan perawatan lebih tinggi.

Fungsi dari Variable Speed Drive (VSD) adalah menurunkan kecepatan fan untuk memenuhi kebutuhan aliran yang dibutuhkan. Ada beberapa jenis VSD yang biasa digunakan yaitu : VSD Mekanik, listrik dan Variable Frequency Drive. Variable Speed Drive (VSD) dapat digolongkan menjadi 2 yaitu VSD mekanik dan VSD listrik. VSD mekanik mempunyai beberapa type seperti kopling hidrolik, kopling fluida, dengan belt dan pully yang dapat diatur, sedangkan VSD listrik typenya adalah kopling arus eddy, pengendali motor dengan rotor, Jenis lainnya adalah Variable Frequency Drive, dimana cara kerjanya adalah mengubah kecepatan putaran motor dengan mengatur frekwensi daya yang dipasok).

Inlet Guide vanes: adalah salah satu pengatur kecepatan yang mudah pemasangannya. Keuntungan dari inlet guide vanes ini adalah dapat memperbaiki efisiensi dengan biaya yang cukup murah dengan syarat aliran udara yang digunakan di antara 80-100\% dari kapasitas maksimum. Apabila kurang dari $80 \%$ dari 
kecepatan maksimum maka efisiensi yang didapat tidak terlalu baik.

Variable pitch fans juga merupakan salah satu pengatur kecepatan fan yang menciptakan pusaran ke arah fan sehingga dapat memperkecil sudut antara udara yang masuk dan blade fan,

Langkah yang dilakukan adalah dengan merubah sudut antara aliran udara yang masuk dan blade yaitu dengan memiringkan blade fan sehingga menurunkan beban motor, tekanan dan aliran udara fan.

Keuntungan dari Variable pitch fans selain dapat menjaga efisiensi tinggi diatas kisaran kondisi operasi juga menghindarkan timbulnya gaung ketukan kecepatan operasi normal dicapai. Keuntungan yang lain adalah dapat beroperasi dari kondisi tanpa aliran sampai aliran penuh tanpa adanya masalah kegagalan.

Akan tetapi Variable pitch fans juga mempunyai beberapa kendala seperti hanya dapat diterapkan pada beberapa jenis fan aksial saja, selain itu akan timbul masalah kotoran jika bahan pencemar terakumulasi dalam actuator mekanis yang mengendalikan blades. Pada beban yang rendah untuk jangka waktu lama dapat mengurangi faktor daya dan efisiensi motor

Pada penelitian sebelumnya, penulis telah melakukan kajian penggantian damper dengan VSD berdasarkan asumsi penghematan yang dapat dilakukan oleh sebuah VSD dengan merk hitachi yang melalui perubahan variabel prosentase pada bukaan damper dari $0 \%$ s/d $100 \%$. Dari hasil kajian ini dapat diketahui bahwa perubahan damper dengan VSD dapat menghasilkan penghematan energi yang besar.

\subsection{Tujuan Penelitian}

Tujuan penelitian ini adalah untuk memperoleh penghematan energi secara real pada fan melalui penggantian damper dengan VSD.

\section{METODE DAN PERALATAN}

\subsection{METODOLOGI}

Dalam penelitian dilakukan langkahlangkah sebagai berikut :

a. Melakukan pengukuran daya pada 6 buah fan yang akan dipasang VSD elektrik seperti : persentase bukaan damper, desain, konsumsi daya aktual dan laju alir aktual.

b. Melakukan pengukuran daya pada pemakaian VSD elektrik di 6 buah fan dari desain sampai dengan actual output.

c. Menghitung besarnya penghematan dengan membandingkan pemakaian daya pada fan yang menggunakan damper dengan yang memakai VSD.

\subsection{Peralatan}

Dalam penelitian ini digunakan per alatan utama yaitu :

a. Peralatan Pengukur listrik model HIOKI 3286-20 Clamp-on Power Hitester digunakan untuk mengukur Parameter Utama (KVA, kW, PF, Hertz, KVAr, Ampere dan Volt.

b. Peralatan Pengukur Kecepatan motor jenis stroboscope.

\section{HASIL DAN PEMBAHASAN}

Spesifikasi teknis masing-masing Fan yang digunakan dalam penelitian dapat dilihat pada Tabel 1.

Tabel 1. Spesifikasi Teknis Fan

\begin{tabular}{|c|c|c|c|c|}
\hline \multirow{2}{*}{$\begin{array}{l}\text { HASC } \\
\text { MOTOR }\end{array}$} & \multicolumn{4}{|c|}{ DEGGN } \\
\hline & KNW & VOLT & AMP. & RFM \\
\hline $471-F N 4$ & 110 & 400 & 195 & 1485 \\
\hline $471-F N 5$ & 110 & 400 & 195 & 1485 \\
\hline 471 -FNE & 110 & 400 & 195 & 1485 \\
\hline 471 -FNT & 110 & 400 & 195 & 1485 \\
\hline $471-F N 8$ & 55 & 400 & 98 & 1475 \\
\hline 471 -FNg & 55 & 400 & 98 & 1475 \\
\hline
\end{tabular}


Hasil pengukuran pemakaian energi terhadap 6 buah fan sebelum dilakukan pemasangan inverter/VSD'S (masih menggunakan damper) yang telah dilaksanakan dari tanggal 26 november 2004 sampai dengan 1 maret 2005 disajikan pada Tabel 2. Pengukuran ini sangat penting untuk mengetahui seberapa besar pengaruh penggantian damper dengan inverter yang akan dilaksanakan.

Untuk melaksanakan proses penggantian inverter pada 6 (enam) buah Fan, dibutuhkan waktu lebih kurang 3 bulan yang dilaksanakan pada tanggal 8 april 2005 sampai dengan 20 april 2005.

Pengukuran telah dilaksanakan 2 periode, periode I pada tanggal 8 april 2005 sampai dengan 20 april 2005 dan periode II pada pada tanggal 1 september 2005 sampai dengan 6 september 2005. Hasil pengukuran masing masing Fan dapat dilihat pada Table 3 dan Tabel 4.
Tabel 2 memberikan gambaran pada kondisi awal Flow Range masing-masing motor yang dihasilkan sebelum dilaksanakan penggantian inverter sesuai dengan pengaturan persentase damper range pada motor yang digunakan. Dari hasil data yang diperoleh dapat dihitung bahwa proses ini memerlukan energi sebesar $267,76 \mathrm{KWH}$.

Dengan tanpa merubah Flow Range yang dihasilkan masing-masing Fan, pada periode I pengamatan hasil penggantian damper dengan inverter menunjukkan terjadi penurunan kebutuhan energi menjadi $203,01 \mathrm{KwH}$, dengan perincian untuk masing-masing Fan sebesar : a. HAC Motor jenis 471-FN4 (13,45 KWH), b. Jenis 471FN5 (19.43 KWH), c. Jenis 471-FN6 (12,76 $\mathrm{KWH})$, d. Jenis 471-FN7 (4.43 KWH), Jenis 471-FN8 (8,15 KWH), dan Jenis 471-FN9 $(6,74 \mathrm{KWH})$, atau telah terjadi penghematan penggunaan energi sebesar 64,96 KWH. Hasil ini tidak banyak berubah terhadap hasil pengamatan pada periode II (Tabel 4).

Tabel 2 : Pemakaian Energi Rata-rata Masing-masing Fan Menggunakan Damper

\begin{tabular}{|c|c|c|c|c|c|c|c|}
\hline \multirow{2}{*}{$\begin{array}{l}\text { Feed } \\
\text { range }\end{array}$} & \multirow{2}{*}{$\begin{array}{l}\text { HAC } \\
\text { MOTOR }\end{array}$} & \multirow{2}{*}{$\begin{array}{l}\text { 哃 damper } \\
\text { range }\end{array}$} & \multirow{2}{*}{$\begin{array}{l}\text { Flowrange } \\
\text { ( Nm3/hr) }\end{array}$} & \multicolumn{3}{|c|}{ ACTUAL OUTPUT } & \multirow[t]{2}{*}{ ASSUMPTION } \\
\hline & & & & $\begin{array}{l}\text { Amp } \\
\text { range }\end{array}$ & PF range & $\begin{array}{c}\text { Average } \\
\text { power (KW) }\end{array}$ & \\
\hline \multirow{6}{*}{$270-310$ thr } & 471-FN4 & $35 \sim 45$ & $35,644 \sim 45,547$ & $105^{2} 111$ & $0.83 \sim 0.85$ & 61.40 & \multirow{6}{*}{$\begin{array}{l}\text { Energy price: } \\
\text { Rp. } 600 / \text { KonHH. } \\
\text { Operating days: } \\
320 \text { days }\end{array}$} \\
\hline & 471-FN5 & $34 \sim 4$ & $27,644 \sim 3,236$ & $108 \sim 117$ & $0.84 \sim 0.88$ & 67.40 & \\
\hline & 471-FN6 & $34 \sim 4$ & $27,153 \sim 34,279$ & $85 \sim 88$ & $0.77 \sim 0.88$ & 47.20 & \\
\hline & 471-FN7 & $44 \sim 60$ & $24,562 \sim 4,228$ & $75 \sim 80$ & $0.73^{\sim 0} 0.77$ & 39.38 & \\
\hline & 471-FN8 & $20 \sim 50$ & $26,102 \sim 27,608$ & $42 \sim 50$ & $0.74 \sim 0.80$ & 24.70 & \\
\hline & 471-FN9 & $30 \sim 40$ & $27,309 \sim 34,390$ & $43 \sim 51$ & $0.79 \sim 0.81$ & 27.68 & \\
\hline
\end{tabular}

Penghematan Energi Pada... J.Tek.Ling. 10 (1): 62 - 68 
Tabel 3 : Pemakaian Energi Rata-rata masing-masing Fan Menggunakan Inverter (VSD's).

\begin{tabular}{|c|c|c|c|c|c|c|c|c|c|}
\hline \multirow{2}{*}{$\begin{array}{l}\text { Feed } \\
\text { range }\end{array}$} & \multirow{2}{*}{$\begin{array}{l}\text { HAC } \\
\text { MOTOR }\end{array}$} & \multirow{2}{*}{$\begin{array}{l}\text { speed } \\
\text { range } \\
\text { (rpm) }\end{array}$} & \multirow{2}{*}{$\begin{array}{c}\text { Flow } \\
\text { range } \\
\text { (IIm3/hr) }\end{array}$} & \multicolumn{3}{|c|}{ ACTUAL OUTPUT } & \multicolumn{3}{|c|}{$\begin{array}{l}\text { SAVIIIG EIIERGY } \\
\text { CALCULATIOII }\end{array}$} \\
\hline & & & & $\begin{array}{l}\text { Amp } \\
\text { range }\end{array}$ & $\begin{array}{c}\text { PF } \\
\text { range }\end{array}$ & $\begin{array}{c}\text { Average } \\
\text { power } \\
\text { (KW) }\end{array}$ & КWH & $\begin{array}{l}\text { Daily } \\
\text { (Rp) }\end{array}$ & $\begin{array}{l}\text { Yearly } \\
\text { (Rp) }\end{array}$ \\
\hline \multirow{6}{*}{$270-310$ then } & $4 T 1-F N 4$ & $921 \sim 1152$ & $32,500 \times 43,854$ & $82 \sim 97$ & $0.92 \sim 0.95$ & 47.95 & 13.45 & 193,680 & $61,9 \pi, 600$ \\
\hline & $471-F N 5$ & $930 \times 1221$ & $29,839 \times 45,333$ & $79 \times 102$ & $0.93^{\sim 0.97}$ & 47.97 & 19.43 & 279,792 & $89,533,440$ \\
\hline & $471-F N 6$ & $920 \times 1155$ & $32,990 \sim 61,660$ & $30^{2} 36$ & $0.93 \sim 0.97$ & 34.45 & 12.75 & 183,600 & $58,752,000$ \\
\hline & $4 T 1-F N T$ & $948^{\prime}+27 \mathrm{~g}$ & $24,680 \wedge 56,154$ & $66^{\sim 75}$ & $0.91 \sim 0.9 T$ & 35.15 & 4.43 & 63,792 & $20,413,440$ \\
\hline & $4 T$ 1-FN8 & $804 \times 1083$ & $30,585^{\wedge} 39,205$ & $34 \times 44$ & $0.93^{\sim} 0.98$ & 16.55 & 8.15 & 117,350 & $37,555,200$ \\
\hline & $4 T 1-F N G$ & $963^{n}+1005$ & $30,395^{\wedge} 34,200$ & $43^{m} 48$ & $0.91 \sim 0.95$ & 20.94 & 6.74 & 97,055 & $31,057,920$ \\
\hline \multicolumn{7}{|c|}{ Jumlah } & 64.95 & 965,290 & $299,289,000$ \\
\hline
\end{tabular}

Tabel 4 : actual energi yang digunakan oleh fan yang menggunakan Inverter

\begin{tabular}{|c|c|c|c|c|c|c|c|c|c|}
\hline \multirow{2}{*}{$\begin{array}{l}\text { Feed } \\
\text { range }\end{array}$} & \multirow{2}{*}{$\begin{array}{c}\text { HAC } \\
\text { MOTOR }\end{array}$} & \multirow{2}{*}{$\begin{array}{l}\text { speed } \\
\text { range } \\
\text { (rpm) }\end{array}$} & \multirow{2}{*}{$\begin{array}{c}\text { Flow range } \\
\text { (Mm3hr) }\end{array}$} & \multicolumn{3}{|c|}{ ACTUAL OUTPUT } & \multicolumn{3}{|c|}{$\begin{array}{l}\text { SANING ENERGY } \\
\text { CALCULATION }\end{array}$} \\
\hline & & & & $\begin{array}{l}\text { Amp } \\
\text { range }\end{array}$ & $\begin{array}{c}\text { PF } \\
\text { range }\end{array}$ & $\begin{array}{c}\text { Ayerage } \\
\text { power } \\
\text { (KW) }\end{array}$ & KWH & $\begin{array}{l}\text { Daily } \\
\text { (Rp) }\end{array}$ & $\begin{array}{l}\text { Yearly } \\
\text { (Rp) }\end{array}$ \\
\hline \multirow{6}{*}{$294-\$ 18 \mathrm{t} / \mathrm{hr}$} & $4 T 1-F N 4$ & $954 \times 1152$ & $26,600 \times 39,000$ & $82 \sim 102$ & $0.73 \sim 0.98$ & 48.20 & 13.20 & 190,080 & $60,825,600$ \\
\hline & $471-\mathrm{FN} 5$ & $950^{N}+160$ & $20,500 \times 37,800$ & $72^{\sim 101}$ & $0.93 \sim 0.97$ & 45.02 & 22.38 & 322,272 & $103,12 T, 040$ \\
\hline & $4 T 1-\mathrm{FN} 6$ & $960 \times 1160$ & $17,300^{\sim} 34,700$ & $68 \sim 85$ & $0.76 \sim 0.99$ & 36.72 & 10.48 & 150,912 & $48,291,840$ \\
\hline & $4 T 1-F N T$ & $1150 \sim 1250$ & $24,500 \times 47,100$ & 7481 & $0.75 \backsim 0.97$ & 39.56 & 0.02 & 288 & 92,160 \\
\hline & $4 T 1-F N 8$ & $820 \times 950$ & $22,700^{31,800}$ & $34 \times 42$ & $0.78 \sim 0.98$ & 15.45 & 9.24 & 133,056 & $42,5 \pi, 920$ \\
\hline & $4 T 1-F N g$ & $860 \times 950$ & $19,300 \times 22,500$ & $38 \times 45$ & $0.7 T \leadsto 0.98$ & $18.0 T$ & 9.61 & 138,384 & $44,282,880$ \\
\hline \multicolumn{7}{|c|}{ Jumlah } & 64.93 & 934,992 & $299,197,440$ \\
\hline
\end{tabular}

Dari hasil perubahan damper dengan inverter tersebut dapat diperoleh beberapa keuntungan, baik keuntungan finansial maupun keuntungan lingkungan.
Keuntungan finansial dari penghematan konsumsi energi dapat dihitung sebagai berikut : 
- Penghematan energi : 64,96 KWH

- $\quad$ Biaya Energi = Rp 600,- per kWh

Dengan asumsi fan beroperasi penuh 24 jam/hari selama 320 hari pertahun, maka penghematan tahunan yang dapat diperoleh sebesar:

$$
\begin{aligned}
= & 64,96 \mathrm{KWH} \times 24 \text { jam x } 320 \text { hari } \\
& \times \text { Rp. 600,- } \\
= & \text { Rp 299.427.840,- }
\end{aligned}
$$

Dengan memperhitungkan besarnya investasi yang diperlukan untuk mengganti/ merubah damper dengan inverter pada 6 (enam) buah fan sebesar Rp. 600.000.000,, maka waktu pengembalian modal (Break Event Point) adalah :

$$
\underline{600.000 .000,-}=2 \text { tahun }
$$$$
\text { 299.427.840,- }
$$

Waktu pengembalian modal dalam jangka waktu 2 tahun sebagaimana yang telah diperoleh dari penghematan konsumsi energi ini dipandang sangat ekonomis, sehingga pada tahun ke tiga dan seterusnya industri semen ini dapat memetik keuntungan Rp 299.427.840,- untuk penggantian inverter pada 6 buah fan yang dioperasikan.

Sedangkan keuntungan lingkungan yang diperoleh dari penghematan energi terhadap penggantian 6 inverter adalah sebesar :

- Penghematan Daya pertahun

$=64,96 \mathrm{KWH} \times 24$ jam $\times 320$ hari

$=499.046,4 \mathrm{KWH} /$ tahun

$=499,0464 \mathrm{MWH} /$ tahun

- Penurunan emisi gas rumah kaca $(\mathrm{GHG})^{3,4]}$

$$
\begin{aligned}
= & 499,0464 \mathrm{MWH} / \text { tahun } \times 0.724 \\
& \text { ton } \mathrm{CO}_{2} / \text { tahun } \\
= & 361,31 \text { Ton } \mathrm{CO}_{2} / \text { tahun }
\end{aligned}
$$

Mengingat pada operasionalnya, industri semen yang menjadi obyek penelitian ini menggunakan 12 fan, maka apabila dapat dilakukan penggantian inverter pada 6 (enam) buah fan yang lain maka keuntungan finansial yang diperoleh pada tahun ketiga dan seterusnya sebesar Rp. 598.855.680,dan keuntungan lingkungan sejak dilaksanakannya penghematan energi sebesar 722,62 Ton CO2/tahun suatu nilai yang cukup signifikan untuk berkontribusi bagi penurunan dampak GRK.

\section{KESIMPULAN DAN SARAN}

\subsection{Kesimpulan}

Berdasarkan hasil dan pembahasan yang telah dikemukakan diatas, maka dapat ditarik kesimpulan sebagai berikut :

1. Penggantian damper dengan inverter telah dapat menghemat konsumsi energi sekitar $500 \mathrm{MWH} /$ tahun atau setara dengan nilai Rp. 300.000.000,-/ tahun.

2. Walaupun penambahan Inverter pada motor fan cukup mahal, namun dengan mempertimbangkan penghematan yang diperoleh namun waktu pengembaliannya atau break efen pointnya (BEP) hanya sekitar 2 (tahun), sehingga pada tahun ke 3 dan seterusnya sudah merupakan keuntungan perusahaan. BEP 2 tahun ini secara standar kelayakan, masih dianggap menguntungkan.

3. Penghematan konsumsi energi ini secara langsung dapat berkontribusi terhadap upaya penurunan pemanasan global (Global Warming) yang cukup signifikan.

\subsection{Saran}

Penghematan konsumsi energi melalui penggantian inverter ini baru merupakan bagian kecil dari usaha penghematan yang dapat dilakukan pada industri semen. Untuk itu disarankan dapat dilakukan penghematan energi secara menyeluruh melalui penerapan metoda produksi bersih. 


\section{DAFTAR PUSTAKA}

1. Prayudi,T.,2006. Pemasangan variable speed drives (vsd) pada fan untuk menurunkan penggunaan listrik $\mathrm{Di}$ industri semen, J.Tek.Ling, Edisi Khusus, Hal. $28-35$, Jakarta,

2. ................., 1989, Energy Efficiency and Renewable Energy, Improving Fan System Performancea sourcebook for industry, US Department of Energy (US DOE).
3. ..................,"Pedoman Efisiensi Energi Untuk Industri Asia" Geriap Project, UNEP, 2005.

4. Sumber dari penghitung Gas Rumah Kaca UNEP: www.uneptie.org/energy/ tools/ghgin/ 